\title{
PENGARUH SERVICE QUALITY, SERVICE CONVENIENCE, DAN PERCEIVED PRICE AND FAIRNESS TERHADAP LOYALITAS NASABAH BANK DENGAN KEPUASAN NASABAH SEBAGAI VARIABEL MEDIASI
}

\author{
Fincent Sutanto \\ Program Studi Magister Manajemen Universitas Tarumanagara \\ fincentsutanto@gmail.com \\ Keni \\ Program Studi Magister Manajemen Universitas Tarumanagara \\ Masuk : 04-06-2020, revisi : 25-06-2020 diterima untuk diterbitkan : 26-06-2020
}

\begin{abstract}
The purpose of this research is to investigate the effects of service quality, service convenience and perceived price and fairness on banking customer loyalty with customer satisfaction as the mediating at the bank. The method to sample the bank's customers was by using non-probability sampling method with convenience sampling technique. The instruments to collect the data was by distributing questionnaires to 244 respondents of bank's in Jakarta. Method to analysed the data was by using PLS-SEM. The result of the research revealed that service quality and perceived price and fairness have positive impacts on customer loyalty, while service convenience has no effect on customer loyalty. This research also found that service convenience and perceived price and fairness have positive impacts on customer satisfaction, while service quality has no effect on customer satisfaction. Moreover, customer satisfaction acts as mediating variable between service convenience. The finding suggest bank should maintain and enhance for service quality and perceived price and fairness to encourage customers decision to repurchase or remain a customer.
\end{abstract}

Abstrak: Tujuan penelitian ini untuk mengetahui pengaruh kualitas layanan, kenyamanan layanan dan kelayakan harga yang dirasakan terhadap loyalitas pelanggan dengan kepuasan nasabah sebagai variabel mediasi terhadap nasabah bank. Penelitian ini menggunakan metode non-probability sampling dengan teknik convenience sampling. Penulis mengumpulkan 244 responden untuk penelitian ini dari nasabah bank swasta di Jakarta yang sebagian besar adalah karyawan umum. Respons dianalisis menggunakan PLS-SEM. Hasil penelitian menunjukkan bahwa kualitas layanan dan persepsi harga dan keadilan memiliki dampak positif terhadap loyalitas pelanggan, kenyamanan layanan tidak berpengaruh terhadap loyalitas pelanggan. Penelitian ini juga menemukan bahwa kenyamanan layanan dan persepsi harga dan keadilan memiliki dampak positif pada kepuasan pelanggan dan kualitas layanan tidak berpengaruh pada kepuasan pelanggan. Selain itu, kepuasan pelanggan bertindak sebagai variabel perantara antara kenyamanan layanan. Temuan ini menyarankan bank harus menjaga dan meningkatkan kualitas layanan serta harga dan keadilan yang dirasakan untuk mendorong keputusan pelanggan untuk membeli kembali atau tetap menjadi pelanggan.

Keywords: Service Quality, Service Convenience, Perceived Price and Fairness, Customer Satisfaction, Customer Loyalty

\section{PENDAHULUAN}

Bank merupakan industri jasa memiliki peranan penting dalam pertumbuhan ekonomi. Dalam sektor bisnis bank berperan atas keberlangsungan proses industri lainnya. Banyaknya bank dengan menawarkan keunggulan masing-masing membuat kompetitifnya industri jasa yang satu ini. Dengan banyaknya bank pesaing, membangun dan mempertahankan hubungan dengan nasabah menjadi faktor penting keberlangsungan bisnis bank. 
Menurut Griffin (2005) pelanggan yang loyal mampu merekomendasikan bank kepada orang lain, sehingga membuat pelanggan menjadi loyal merupakan aset penting bagi bank dalam menjalankan bisnisnya. Dalam hal ini para nasabah dapat menjadi loyal dipengaruhi kepada kepuasan saat bertransaksi atau menggunakan fasilitas bank. Nasabah yang sudah didasari kepercayaan terhadap bank mampu mendorong loyalitasnya terhadap bank tertentu (Kaura et al., 2015).

Karyose et al. (2017) dalam penelitiannya mengungkapkan menciptakan loyalitas nasabah dipengaruh dari kualitas layanan yang didapatkan oleh nasabah. Pelayanan yang baik akan mendorong nasabah tetap menggunakan bank tersebut. Lebih lanjut Kaura et al. (2015) kenyamanan nasabah terhadap bank akan dapat menentukan keputusan nasabah untuk tetap bertahan menjadi nasabah dan puas terhadap bank.

Kaura et al. (2015) menyatakan kelayakan dari biaya yang dikeluarkan nasabah mempengaruhi loyalitas nasabah. Biaya yang ditimbulkan dari fasilitas yang diberikan bank kepada para nasabahnya akan dinilai oleh para nasabah apakah biaya yang mereka keluarkan untuk mendapatkan fasilitas tersebut layak. Serta menciptakan kepuasan atas kelayakan harga yang diberikan bank dapat meningkatkan keputusan nasabah untuk loyal terhadap bank. Berdasarkan latar belakang di atas, maka tujuan dari penelitian ini adalah untuk mengidentifikasi pengaruh service quality, service convenience dan perceived price and fairness terhadap kepuasan nasabah dengan kepuasan nasabah sebagai variabel mediasi.

\section{TELAAH KEPUSTAKAAN \\ Service Quality}

Tjiptono (2012:157) mendefinisikan "kualitas pelayanan adalah ukuran seberapa bagus tingkat layanan yang diberikan mampu sesuai dengan ekspektasi pelanggan.” Jadi dapat disimpulkan kualitas pelayanan merupakan ukuran perbandingan antara harapan yang diekspektasikan oleh konsumen dengan apa yang didapatkan oleh konsumen.

\section{Service Convenience}

Kaura et al. (2015:406) mendefinisikan "service convenience is an idea and thought of adding value to the customers/tourists and reducing the effort and time that customers spend." Jadi dapat disimpulkan persepsi dari pelanggan yang mengacu pada upaya dan waktu yang dihabiskan pelanggan dalam mendapatkan atau menerima pelayanan.

\section{Perceived Price and Fairness}

Asadi et al. (2014: 203) mendefinisikan "perceived price and fairness, as a judgment of whether an outcome and/or the process to reach an outcome are reasonable, acceptable or just”. Sehingga dapat disimpulkan perceive price and fairness merupakan sebuah penilaian dari pelanggan terhadap apa yang didapatkan sebanding dengan harga yang dibayarkan.

\section{Kepuasan Nasabah}

Karyose et al. (2017: 339) mendefinisikan, "customer satisfaction is an after-sales assessment whereby the selected alternative is at least equal to or exceeds the customer expectations, whereas dissatisfaction emerger when the result do not meet expectations". Sehingga dapat disimpulkan kepuasan nasabah merupakan harapan yang ditaruh pelanggan atau konsumen pada suatu produk barang atau jasa terhadap tindakan atau hasil yang diterima.

\section{Loyalitas Nasabah}

Karyose et al. (2017: 339) mendefinisikan, "customers loyalty is directed to a behavior, which is indicated by regular purchases, based on the decision-making unit." Maka dapat disimpulkan jika loyalitas merupakan perilaku konsumen untuk tetap melakukan pembelian kembali terhadap suatu produk atau layanan didasari pada evaluasi pembelian sebelumnya.

\section{Pengaruh service quality, service convenience dan perceived price and fairness terhadap customer loyalty}

Menurut penelitian Kaura (2015) menemukan bahwa kualitas pelayanan memiliki pengaruh positif terhadap loyalitas nasabah. Kemudian penelitian Delic (2017) menemukan 
bahwa service convenience memiliki pengaruh signifikan positif terhadap customer loyalty. Serta hasil penelitian Asadi (2014) menemukan jika perceived price memiliki pengaruh terhadap loyalitas pelanggan. Berdasarkan paparan di atas, maka hipotesis penelitian adalah sebagai berikut:

H1a: Terdapat pengaruh positif service quality terhadap customer loyalty

H1b: Terdapat pengaruh positif service convenience terhadap customer loyalty

H1c: Terdapat pengaruh positif perceived price and fairness terhadap customer loyalty

Pengaruh service quality, service convenience dan perceived price and fairness terhadap customer satisfaction

Menurut penelitian Kaura (2015) menemukan bahwa kualitas layanan dan kenyamanan layanan memiliki pengaruh positif terhadap kepuasan pelanggan. Serta hasil penelitian yang dilakukan Asadi (2014) menemukan adanya hubungan bahwa kelayakan harga mempengaruhi secara positif terhadap kepuasan pelanggan. Berdasarkan paparan di atas, maka hipotesis penelitian adalah sebagai berikut:

$\mathrm{H} 2 \mathrm{a}$ : Terdapat pengaruh positif service quality terhadap customer satisfaction

$\mathrm{H} 2 \mathrm{~b}$ : Terdapat pengaruh positif service convenience terhadap customer satisfaction

$\mathrm{H} 2 \mathrm{c}$ : Terdapat pengaruh positif perceived price and fairness terhadap customer satisfaction

Pengaruh customer satisfaction terhadap customer loyalty

Menurut penelitian Karyose (2017) menemukan jika kepuasan memiliki pengaruh yang positif terhadap loyalitas pelanggan. Secara umum dinyatakan bahwa pelanggan yang puas terhadap layanan produk atau jasa akan berdampak positif terhadap loyalitas pelanggan sehingga mendorong pelanggan untuk melakukan pembelian berulang. Berdasarkan paparan di atas, maka hipotesis penelitian adalah sebagai berikut:

H3: Terdapat pengaruh positif customer satisfaction terhadap customer loyalty

Customer satisfaction memediasi pengaruh service quality, service convenience dan perceived price and fairness terhadap customer loyalty

Menurut penelitian Bakti (2012) menemukan hasil jika kepuasan pelanggan memediasi pengaruh dari kualitas layanan terhadap loyalitas pelanggan. Kemudian hasil penelitian Kaura (2015) menemukan jika kepuasan pelanggan memediasi pengaruh hubungan antara kenyamanan layanan dan kelayakan harga dengan loyalitas pelanggan. Berdasarkan paparan di atas, maka hipotesis penelitian adalah sebagai berikut:

H4a: Customer satisfaction dapat memediasi pengaruh service quality terhadap customer loyalty

H4b: Customer satisfaction dapat memediasi pengaruh service convenience terhadap customer loyalty

H4c: Customer satisfaction dapat memediasi pengaruh perceived price and fairness terhadap customer loyalty

Berdasarkan uraian kaitan antar variabel di atas, maka model penelitian adalah sebagai berikut:

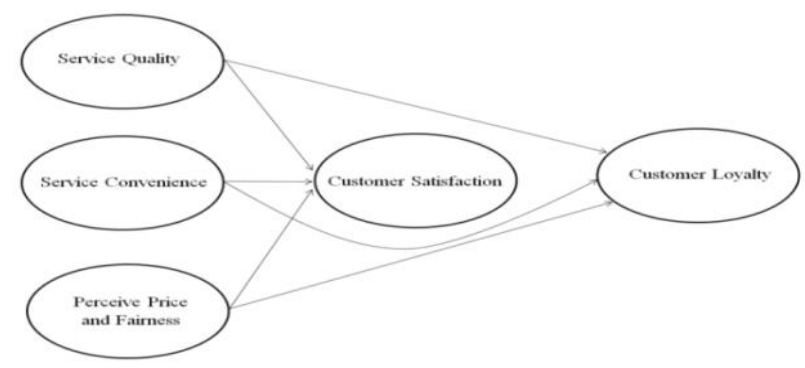

Gambar 1

Model Penelitian 


\section{METODOLOGI PENELITIAN}

Penelitian ini merupakan penelitian deskriptif. Populasi dalam penelitian ini adalah nasabah salah satu bank swasta di Jakarta. Metode pengambilan sampel dalam penelitian ini adalah metode non-probability sampling dimana setiap unsur yang terdapat didalam populasi tidak memiliki kesempatan atau peluang yang sama dalam pemilihan sebagai sampel. Sementara teknik pemilihan sampel yang digunakan dalam penelitian ini adalah convenience sampling. Sampel dalam penelitian ini sebesar 244 nasabah salah satu bank swasta di Jakarta.

Beberapa instrumen diadaptasi dari penelitian terdahulu untuk mengukur variabel penelitian, pengukuran objek penelitian diukur menggunakan skala Likert lima poin dengan 1 menunjukan "sangat tidak setuju" dan 5 menunjukan "sangat setuju".

Pengumpulan data pada penelitian ini dilakukan dengan pembagian kuesioner secara online dengan menggunakan google-form kepada para nasabah salah satu bank swasta di Jakarta. Metode analisis data dalam penelitian ini menggunakan structure equation modeling (SEM) dengan bantuan program SmartPLS 3.3.2. taraf signifikansi yang digunakan pada penelitian ini adalah sebesar 5\%. Operasional variabel penelitian ini diadaptasi dari Kaura et al. (2015) dengan rincian variabel service quality 15 item, service convenience 17 item, perceived and fairness 6 item, customer satisfaction 3 item dan customer loyalty 5 item.

\section{HASIL ANALISIS DAN PEMBAHASAN}

Hasil pengujian koefisien determinasi $\mathrm{R}^{2}$ dari penelitian ini menunjukan nilai presentase variabel customer loyalty sebesar 77,6\% dan customer satisfaction sebesar 63\%. Kemudian berdasarkan hasil pengujian predictive relevance $\left(\mathrm{Q}^{2}\right)$ yang menunjukan nilai sebesar 0,603 untuk customer loyalty dan sebesar 0,545 untuk customer satisfaction yang dapat dikategorikan kuat. Hasil analisis data secara singkat tertera pada Tabel 1 berikut ini:

\section{Tabel 1}

Hasil Pengujian Hipotesis

\begin{tabular}{|c|c|c|c|}
\hline \multicolumn{2}{|c|}{ Hipotesis } & \multirow{2}{*}{$\begin{array}{l}\text { Coefficient } \\
0,122\end{array}$} & \multirow{2}{*}{$\begin{array}{l}\text { T-statistic } \\
2,271 *\end{array}$} \\
\hline H1a & Service Quality -> Loyalitas Nasabah & & \\
\hline $\mathrm{H} 1 \mathrm{~b}$ & Service Convenience -> Loyalitas Nasabah & 0,082 & $1,046^{*}$ \\
\hline $\mathrm{H} 1 \mathrm{c}$ & Perceived Price and Fairness $->$ Loyalitas Nasabah & 0,209 & $4,676^{*}$ \\
\hline $\mathrm{H} 2 \mathrm{a}$ & Service Quality -> Kepuasan Nasabah & 0,115 & $1,440 *$ \\
\hline $\mathrm{H} 2 \mathrm{~b}$ & Service Convenience -> Kepuasan Nasabah & 0,604 & $6,808^{*}$ \\
\hline $\mathrm{H} 2 \mathrm{c}$ & Perceived Price and Fairness $->$ Kepuasan Nasabah & 0,139 & $1,964 *$ \\
\hline $\mathrm{H} 3$ & Kepuasan Nasabah -> Loyalitas Nasabah & 0,579 & $8,699 *$ \\
\hline $\mathrm{H} 4 \mathrm{a}$ & Service Quality -> Kepuasan Nasabah -> Loyalitas Nasabah & 0,066 & $1,398 *$ \\
\hline $\mathrm{H} 4 \mathrm{~b}$ & Service Convenience -> Kepuasan Nasabah -> Loyalitas Nasabah & 0,350 & $6,062 *$ \\
\hline $\mathrm{H} 4 \mathrm{c}$ & Perceived Price and Fairness $->$ Kepuasan Nasabah $->$ Loyalitas Nasabah & 0,080 & $1,913 *$ \\
\hline
\end{tabular}
$* \mathrm{p}<0,05 ; * * \mathrm{p}<0,01$

Berdasarkan Tabel 1. di atas dapat ditarik kesimpulan bahwa variabel perceived and fairness memberikan kontribusi terbesar terhadap customer loyalty yang dibuktikan oleh nilai path coefficients sebesar 0.209. Sementara untuk hasil pengujian hipotesis variabel service quality dan perceived and fairness memiliki pengaruh positif dan signifikan terhadap customer loyalty, sedangkan variabel customer satisfaction terbukti memediasi hubungan antara service convenience dan customer loyalty.

\section{Pembahasan}

Hasil pengujian hipotesis pertama membuktikan service quality mempengaruhi customer loyalty secara positif dan signifikan. Hipotesis ini sesuai dengan penelitian Kaura (2015) yang menyatakan service quality mempengaruhi customer loyalty secara positif dan signifikan. Sehingga memberikan nasabah kualitas layanan terbaik akan meningkatkan loyalitas nasabah terhadap bank tersebut. Kemudian hipotesis ditemukan service convenience tidak signifikan terhadap customer loyalty, hasil ini berbeda dengan penelitian terdahulu yang dilakukan oleh Delic (2017) yang menyatakan jika service convenience berpengaruh secara positif dan signifikan terhadap customer loyalty. Dengan memberikan kenyamanan layanan para nasabah merasa sudah seharusnya bank memberikan kenyamanan yang baik terhadap para nasabahnya, 
sehingga kenyamanan layanan bukan merupakan faktor yang mempengaruhi keputusan nasabah untuk loyal terhadap bank ini. Sedangkan hipotesis menemukan jika perceived price and fairness mempengaruhi customer loyalty secara positif dan signifikan hasil ini sesuai dengan penelitian Asadi (2014) yang menyatakan jika perceived price and fairness berpengaruh secara positif dan signifikan terhadap customer loyalty. Pemberian harga yang ditentukan oleh bank untuk para nasabah mereka tentunya akan mempengaruhi keputusan para nasabah bank untuk tetap loyal terhadap bank tersebut atau beralih ke bank lainnya.

Hasil pengujian hipotesis membuktikan service convenience dan perceived and fairness mempengaruhi customer satisfaction secara positif dan signifikan. Hasil ini sesuai dengan penelitian Kaura (2015) dan penelitian Asadi (2014) yang menyatakan service convenience dan perceived and fairness mempengaruhi customer satisfaction. Dengan memberikan kenyamanan layanan dan pemberian kelayakan harga yang baik akan meningkatkan kepuasan nasabah. Sementara pengujian hipotesis membuktikan service quality tidak signifikan terhadap customer satisfaction, hasil ini berbeda dengan penelitian Kaura (2015) yang menyatakan service quality mempengaruhi customer satisfaction. Kualitas layanan menurut para nasabah sudah seharusnya diberikan oleh bank terhadap para nasabahnya, sehingga kualitas layanan tidak mempengaruhi kepuasan nasabah.

Hasil pengujian hipotesis membuktikan customer satisfaction mempengaruhi secara positif dan signifikan terhadap customer loyalty. Hasil ini sesuai dengan penelitian Karyose (2017) yang menyatakan jika kepuasan memiliki pengaruh yang positif terhadap loyalitas pelanggan. Kepuasan yang dirasakan para nasabah bank akan mempengaruhi keputusan para nasabah untuk tetap menjadi nasabah bank tersebut sehingga bank harus mampu memberikan yang terbaik bagi para nasabahnya hingga mereka merasa puas terhadap yang mereka dapatkan.

Hasil pengujian hipotesis membuktikan variabel customer satisfaction memediasi pengaruh antara service convenience dan customer loyalty. Hasil ini sesuai dengan penelitian Kaura (2015), yang menyatakan customer satisfaction memediasi pengaruh antara service convenience dan customer loyalty. Kenyamanan layanan secara langsung tidak membuat loyal nasabah bank, sehingga kenyamanan layanan harus menciptakan kepuasan nasabah baru akan meningkatkan loyalitas nasabah. Sedangkan hasil pengujian hipotesis menemukan service quality dan perceived price and fairness tidak dimediasi oleh customer satisfaction terhadap customer loyalty. Hasil ini berbeda dengan penelitian Bakti (2012) dan Kaura (2015) yang menyatakan customer satisfaction memediasi service quality dan perceived price and fairness terhadap customer loyalty. Loyalitas nasabah yang dibutuhkan bank secara langsung dipengaruhi oleh kualitas layanan dan kelayakan harga, sehingga bank tidak diharuskan untuk menciptakan kepuasan nasabah terlebih dahulu untuk meningkatkan loyalitas nasabah.

\section{PENUTUP \\ Kesimpulan}

Hasil penelitian H1 menunjukan service quality dan perceived price and fairness memiliki pengaruh positif dan signifikan terhadap customer loyalty dan service convenience memiliki pengaruh positif namun tidak signifikan terhadap customer loyalty. Sedangkan hasil $\mathrm{H} 2$ menunjukan service convenience dan perceived price and fairness memiliki pengaruh positif dan signifikan terhadap customer loyalty dan service quality memiliki pengaruh positif namun tidak signifikan terhadap customer satisfaction. Selanjutnya hasil H3 menunjukan customer satisfaction memiliki pengaruh positif dan signifikan terhadap customer loyalty. Sementara hasil H4 menunjukan customer satisfaction mampu memediasi pengaruh antara service convenience terhadap customer loyalty dan customer satisfaction tidak memediasi pengaruh antara Service quality dan perceived price and fairness terhadap customer loyalty.

\section{Saran}

Peneliti menyarankan agar bank tersebut harus memperhatikan kualitas layanan dan kelayakan harga terhadap para nasabahnya sehingga akan meningkatkan loyalitas nasabah 
bank tersebut. kualitas layanan yang diberikan oleh bank melalui para karyawannya hingga penggunaan fasilitas IT bank dalam mempermudah para nasabahnya untuk bertransaksi. Kelayakan harga yang diberikan oleh bank terhadap pemberian bunga terhadap produk funding dan lending hingga biaya-biaya yang timbul karena layanan yang didapatkan oleh nasabah harus menjadi perhatian bank tersebut guna mempertahankan loyalitas nasabahnya. Kenyamanan layanan juga harus diberikan oleh bank terhadap para nasabahnya guna meningkatkan kepuasan para nasabahnya yang pada akhirnya akan meningkatkan loyalitas nasabah bank tersebut.

\section{DAFTAR RUJUKAN/PUSTAKA}

Asadi, A., Pool, J. K. \& Jalilvand, M. R. (2014). The effect of perceived price fairness through satisfaction and loyalty on international tourist' price acceptance of Islamic-Iranian art products. Education, Business and Society: Contemporary Middle Eastern Issues, 7(4), 201-215.

Bakti, I. G. M. Y. \& Sumaedi, S. (2012). An analysis of library customer loyalty: the role of service quality and customer satisfaction, a case study in Indonesia. Library Management, 34(6/7), 397-414.

Colwell, S. R., Aung, M., Kanetkar, V. \& Holden, A. L. (2008). Toward a measure of service convenience: multiple-item scale development and empirical test. Journal of Service Marketing, 22(2), 160-169.

Delic, M., Knezevic, B. \& Duzevic, I. (2017). Factors influencing customer loyalty towards mobile commerce: The case of young retail customers in Croatia. International Journal of Economic Perspectives, 11(1), 314-325.

Dhasan, D. \& Aryupong, M. (2019). Effect of product quality, service quality and price fairness on customer engagement and customer loyalty. ABAC Journal, 39(2), 82-102.

Griffin, J. (2005). Customer Loyalty: Menumbuhkan \& Mempertahankan Kesetiaan Pelanggan. Jakarta: Erlangga.

Karyose, H., Astuti, W. \& Ferdiansjah, A. (2017). Customer loyalty: The effect of service quality, corporate image, customer relationship marketing and customer satisfaction as intervening variable-an empirical analysis of bank customer in Malang city. Marketing and Branding Research, 4, 336-347.

Kaura, V., Prasad, C. S. D. \& Sourabh, S. (2015). Service quality, service convenience, price and fairness, customer loyalty, and the mediating role of customer satisfaction. International Journal of Bank Marketing, 33(4), 404-422.

Kuo-Chien, C., Mu-Chen, C., Chia-Lin, H., \& Nien-Te, K. (2010). The effect of service convenience on post-purchasing behaviours. Industrial Management \& Data Systems, $110(9), 1420-1443$.

Purnama, S. F. (2019). Pengaruh service convenience terhadap customer loyalty melalui customer satisfaction sebagai variabel mediasi pada atlas sport club Surabaya. AGORA, $7(2), 1-5$.

Samah, I. H. A., Rashid, I. M. A., Rani, M. J. A., Rahman, N. I. A., Ali, M. A. \& Abdulla, M. F. S. (2015). The roles of price perception and and physical environment in determining customer loyalty: Evidence from fast food restaurant of Malaysia. International Journal of Development Research, 5(5), 4366-4370.

Tjiptono, F. \& Chandra, G. (2012). Pemasaran Strategik. Yogyakarta: ANDI

Widodo, R. C. A. \& Shihab, M. S. (2016). Membangun kualitas layanan, kualitas produk, dan presepsi harga untuk mendukung word of mouth melalui kepuasan. Jurnal Management dan Bisnis Sriwijaya, 14(1), 1-16. 